\title{
Effect of canopy position on growth, quality and quantity of Syzygium samarangense (wax apple var. jambu madu) fruits
}

\author{
Mohammad Moneruzzaman Khandaker*, Natasha Qistina Amran, Siti Zuriani Ismail \\ School of Agriculture Science \& Biotechnology, Faculty of Bioresources and Food Industry, Universiti Sultan \\ Zainal Abidin, Besut Campus, 22000 Besut, Terengganu, Malaysia
}

\section{*Corresponding author: moneruzzaman@unisza.edu.my}

\begin{abstract}
This study represents the first report of the effects of tree canopy position on growth, quality and quantity of Syzygium samarangense (wax apple) fruit var. Jambu Madu under tropical condition. A total of five wax apple trees with same height and approximately same number of branches were selected for this study. Each wax apple tree was divided into five different canopy positions by differentiate upper, middle, lower, inner and outer and all of these canopy positions were used as treatments. From the observation, outer canopy position had significant effect on fruit number, fruit size, fruit weight, chlorophyll content and leaves stomatal conductance of wax apple trees. The total soluble solids (TSS) content and percentages of peel color cover were also higher in outer canopy fruits. Based on the findings of the experiment, it was concluded that outer canopy position retain the more number of fruits with better quality compared to other canopy position of the tree.
\end{abstract}

Keywords: Syzygium samarangense, wax apple, canopy position, growth, quality.

\section{Introduction}

Wax apple (Syzygium samarangense) is a non-climacteric tropical fruit from Myrtaceae family (Morton, 1987) that is mostly cultivated in Southeast Asia. The flowers, which contain tannins, desmethoxymatteucinol, 5-O-methyl-40desmethoxymatteucinol, oleanic acid, and b-sitosterol, are used in Taiwan to treat fever and halt diarrhea (Morton, 1987). These edible fruits of S. samarangense represent potential benefits for human health they were rich source of phenolics content, flavonoids and several antioxidant compounds (Shu et al., 2007; Khandaker et al., 2012). The fruits, with either pink, light-red, red, green, sometimes greenish-white, or cream-colored (Morton, 1987), were produced non-seasonal and the peaks period were in February to April and October to December.

To get high yield of fruits, a good light interception is very important (Palmer, 1989). Light reactions are dependent on both the quantity and quality of sunlight (Shahak et al., 2004). Light that is taken by chlorophyll in order to drive photosynthesis process, which affects the soluble solid concentration in fruit (Lambers et al., 1998). Light interception (LI) is that the proportion of light obtainable at the orchard level that falls onto leaves. LI determines the yield potential. Light exposure can possibly to influence the subsequent processes in fruit such as biosynthesis of pigments, fruit carbohydrate utilization, amino acid metabolism as well as acid metabolism (Rudell et al., 2008). Rise in light interception typically found at higher tree densities that provide a large leaf area and more even distribution of light (Palmer, 1989).

An understanding on function of the light is essential especially in agriculture because light plays an important roles on the growth of plant and responsible to produce good quality of fruit. Light responses are dependent on both quality and quantity of light (Shahak et al., 2004). Light energy is absorbed by chlorophyll in order to drive photosynthesis. Climatic variables, specifically light (Bramlage, 1993) and temperature (Frick, 1995) prevailing during fruit growth have a fundamental effect on the post-harvest quality of fruit. The distribution of light within the tree canopy also affect fruit yield (Wunsche and Lakso, 2000) and fruit quality attributes such as fruit size, fruit color (Wagenmakers and Callesen, 1995), and total soluble solids (TSS). Therefore, the fruit quality is related to the amount of light in the vicinity of the developing fruit. Fruit are produced throughout the canopy and are therefore exposed to varying irradiance, ambient temperatures, water and nutrient flow as well as endogenous supply of hormones (Kingston, 1994; Tomala, 1999). Position of the fruit within the canopy of the tree affected fruit quality characteristics. The position effect was probably due to the degree of light exposure and not to the distance from the roots.

As Malaysian climate is suitable for the wax apple fruit production throughout the year, fruit canopy position can influence the quality of wax apple. There are three categories of fruit which is inner fruit, outer fruit, and middle fruit. Different position of canopy receive different amount of light that will affect the fruit quality. Row direction also affects the percentage exposure to full sun of the tree. Therefore, this research will help consumer or grower to recognize the quality of wax apple in order to achieve highest quality fresh fruit and to fulfill the demand of fresh fruit. Thus, this present study will determine the effect of canopy position on the pre and postharvest quality of wax apple fruit produced as well as 
to investigate the best canopy position that produced the best quality of fruit.

\section{Results and Discussion}

The effects of tree canopy position on wax apple fruit quality and quantity were measured by comparing five different positions which were upper canopy (UC), middle canopy (MC), lower canopy (LC), inner canopy (IC), and outer canopy (OC) (Figure 1).

\section{Number of bud, blooming bud and dropped bud per $50 \mathrm{~cm}$ branch and size of bud}

The results showed that the different canopy position produced a significant effect on number of bud $/ 50 \mathrm{~cm}$ branch, number of blooming bud/50 $\mathrm{cm}$ branch, number of dropped bud $/ 50 \mathrm{~cm}$ branch and bud size of wax apple tree (Table 1 and Fig. 2). Number of bud and dropped bud showed the highest reading on the treatment of LC position (accordingly: $58.6 \pm 0.68$ and $36.4 \pm 1.20)$ and the lowest on the UC position (accordingly: $23.4 \pm 0.50$ and $12.4 \pm 0.87$ ), while blooming bud was highest reading on the OC position $(46.0 \pm$ $0.89)$ and size of bud on the UC position $(2.26 \pm 0.02)$. All the parameters showed a significant different among the different canopy position at $\mathrm{P}$-value $(\mathrm{P} \leq 0.05)$ except for size of bud (Fig. 2). This means that the size of bud produced was not affected by the different position of canopy. However, the number of bud, blooming bud and dropped bud were affected by the different position of canopy. Therefore, it suggested that bud at the OC position should be taken care as OC is best position for bud to be bloom.

Our results about lowest bud drop, blooming of bud and size of bud were highest in outer and upper canopy. This may be due to the more availability and higher intensity of light in outer and upper canopy of the wax apple tree. Our findings are supported by the results of Wilkie et al (2008), who reported that light intensity can affect the floral initiation and bud quality of horticultural tress. Some other horticultural techniques, such as removal of young leaves and cytokinin application promote bud development and bud blooming (Moneruzzaman et al., 2010).

\section{Number, length, width and individual weight of fruit}

There are three elements that impact the yield of fruits which is the quantity of light energy that the orchard system will intercept, the proportion of the absorbed light energy that is converted into obtainable carbohydrates and the amount of assimilates allocated into fruits (Wünsche and Lakso, 2000). The treatment of OC showed the highest value of fruit number, fruit length, fruit width and individual fruit weight with $43.2 \pm 1.06,7.13 \pm 0.06 \mathrm{~cm}, 4.29 \pm 0.06 \mathrm{~cm}$ and $57.26 \pm$ $2.02 \mathrm{~g}$, accordingly (Fig. 2). The means differences of all parameters showed a significant different among the five different treatments at $\mathrm{P}$-value $(\mathrm{P} \leq 0.05)$, except for individual weight of fruit which had not affected by the position of canopy. It has been reported that the quantity and proportion of the absorbed light energy converted into carbohydrates and the amount of assimilates allocated into fruits affect the yield and quality of fruits (Wünsche and Lakso, 2000).

The report by Wünsche and Lakso (2000) supported the present result where canopy positions had significantly effect on fruit number produced. Similar findings were recorded on apples (Tahir et al., 2007) where the fruits that were exposed to more light became larger. The light interception determines the yield potential. Therefore, good light interception is necessary to obtain a high yield and high quality of fruit as shown from outer canopy fruits. Previous study found that, the fruits that are constantly exposed to sunlight may differ in quality from shaded fruit and may subsequently have different postharvest attributes (Thompson, 2003). Therefore, the OC position was suggested as the best position for getting a huge number of yields of wax apple fruit.

\section{Effect of canopy position on peel color, TSS content (\% Brix) and firmness of fruit ( $k g$ )}

The outer canopy position had the highest value on peel color $(82.4 \pm 1.16 \%)$, TSS content $(8.52 \pm 0.19 \%$ Brix $)$ and fruit firmness $(10.2 \pm 0.35 \mathrm{~kg})$ of wax apple with significantly different in five different canopy position at $(p \leq 0.05)$ level (Fig. 3). The color of fruits is influenced by the concentration and distribution of anthocyanins, caratenoids and chlorophylls (Steyn, 2012). The synthesis of anthocyanins, responsibles for red color of fruit, requires light (Steyn, 2005). Previous study also reported that fruits from outer canopy are larger and high level of red color than inner canopy position (Lewallen, 2000). This is probably due to fruits at outer canopy were exposed to high intensity of light that then cause greater access to photo-assimilates produced by outer canopy leave as well as fruits.

Total soluble solids measurement is considered to be an important parameter to determine the quality of wax apple. The highest TSS content (\% Brix) of wax apple fruit was recorded in outer canopy position treatment with $8.52 \pm 0.19$ $\%$ Brix followed by lower canopy with $8.20 \pm 0.17 \%$ Brix while, the lowest TSS content was noted in inner canopy position with $6.32 \pm 0.10 \%$ Brix. The mean differences of TSS content in five different treatments showed a significant different at $(\mathrm{P} \leq 0.05)$ level (Fig. 3). This result was supported by Hamadziripi (2012), who found that outer canopy fruit was sweeter, had a higher TSS value, lower titratable acidity and had higher antioxidant capacities. This is probably due to greater access to photo-assimilates produced by outer canopy leaves. The results showed that outer canopy position had the highest value of fruit firmness with a value of $10.2 \pm 0.35 \mathrm{Kg}$ followed by upper canopy position with $8.92 \pm 0.41 \mathrm{Kg}$ (Fig. 3). The lowest value of fruit firmness was recorded in lower canopy position with $7.68 \pm 0.30 \mathrm{Kg}$. The means differences of fruit firmness in five different treatments showed a significant different at $(\mathrm{P} \leq$ 0.05) level. Cresthaven' peaches (Lewallen, 2000) and kiwifruit (Tombesi et al., 1993) that were exposed to highlight environments were firmer than the fruit that grew in shaded or low light environments. Similar finding were recorded by Blanpied et al. (1978) found that shaded inner canopy apples were less firm than outer canopy apples.

The distribution of sunlight within the tree canopy also affects yield (Wünsche and Lakso, 2000) and fruit quality attributes like fruit size, fruit colour (Wagenmakers and Callesen, 1995), total soluble solids (TSS) concentration and titratable acidity (TA) concentration (Lewallen, 2000). As a result of the negative effects of canopy shading (smaller fruits and less red colour), good apple yields were obtained at 70\% light interception (Wagenmakers and Callesen, 1995). Fouché et al. (2010) also found that outer canopy fruit in a 'Granny Smith' orchard were exposed to 54\% (962 $\mu$ molm ${ }^{2} \mathrm{~s}^{1}$ ) of full sun in contrast to the inner canopy fruit that 
Table 1. Effect of different canopy position on number of bud, dropped bud, blooming bud and fruit per $50 \mathrm{~cm}$ branch, chlorophyll content and stomatal conductance of leaf.

\begin{tabular}{|c|c|c|c|c|c|c|}
\hline $\begin{array}{l}\text { Canopy } \\
\text { position }\end{array}$ & $\begin{array}{c}\text { Bud } \\
\text { number }\end{array}$ & $\begin{array}{c}\text { Dropped } \\
\text { bud }\end{array}$ & $\begin{array}{c}\text { Blooming } \\
\text { Bud }\end{array}$ & $\begin{array}{c}\text { Fruit } \\
\text { number }\end{array}$ & $\begin{array}{c}\text { Chlorophyll } \\
\text { content }\end{array}$ & $\begin{array}{c}\text { Stomatal } \\
\text { conductance }\end{array}$ \\
\hline Upper & $23.40^{\mathrm{e}}$ & $12.40^{\mathrm{e}}$ & $11.20^{\mathrm{d}}$ & $8.00^{\mathrm{e}}$ & $44.54^{\mathrm{e}}$ & $63.90^{\mathrm{c}}$ \\
\hline Middle & $43.20^{c}$ & $31.60^{b}$ & $27.00^{c}$ & $26.20^{c}$ & $93.40^{\mathrm{b}}$ & $88.34^{\mathrm{b}}$ \\
\hline Lower & $58.60^{\mathrm{a}}$ & $36.40^{\mathrm{a}}$ & $35.40^{\mathrm{b}}$ & $40.20^{\mathrm{b}}$ & $63.56^{d}$ & $34.04^{\mathrm{e}}$ \\
\hline Inner & $27.20^{\mathrm{d}}$ & $17.40^{\mathrm{d}}$ & $28.60^{\mathrm{c}}$ & $20.00^{d}$ & $77.06^{c}$ & $48.22^{\mathrm{d}}$ \\
\hline Outer & $55.20^{\mathrm{b}}$ & $22.60^{c}$ & $46.00^{\mathrm{a}}$ & $43.20^{\mathrm{a}}$ & $102.3^{4 a}$ & $131.60^{\mathrm{a}}$ \\
\hline
\end{tabular}

Means within the same column followed by the same letter, do not differ significantly according to LSD test at $\dot{\alpha}=0.01, \mathrm{p}$-value $\leq 0.05$.

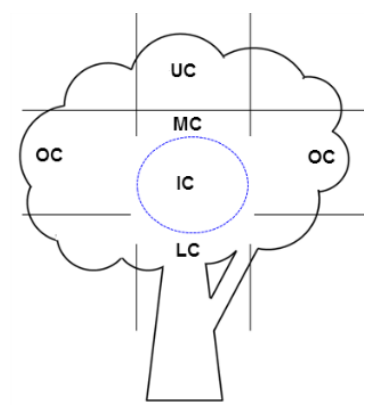

Fig 1. Five (5) different positions of canopy: upper canopy (UC), middle canopy (MC), lower canopy (LC), inner canopy (IC) and outer canopy (OC).

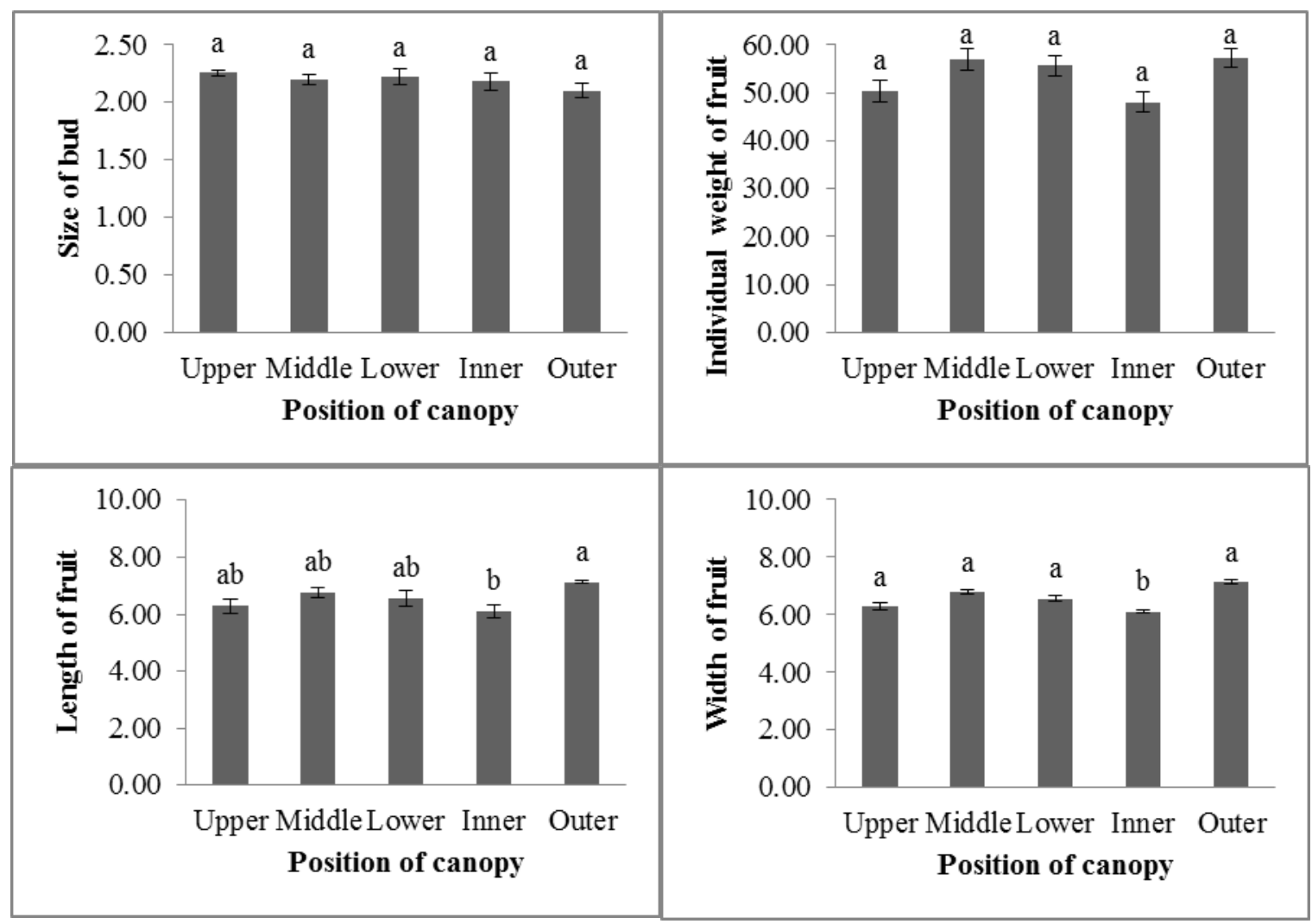

Fig 2. Effects of different canopy position on size of bud $(\mathrm{cm})$, individual weight of fruit $(\mathrm{g})$, length of fruit $(\mathrm{cm})$ and width of fruit $(\mathrm{cm})$. Means within the same column of different line followed by the same letter, do not differ significantly according to LSD test at a $\alpha=0.01$, Bars indicate $( \pm$ S.E). 


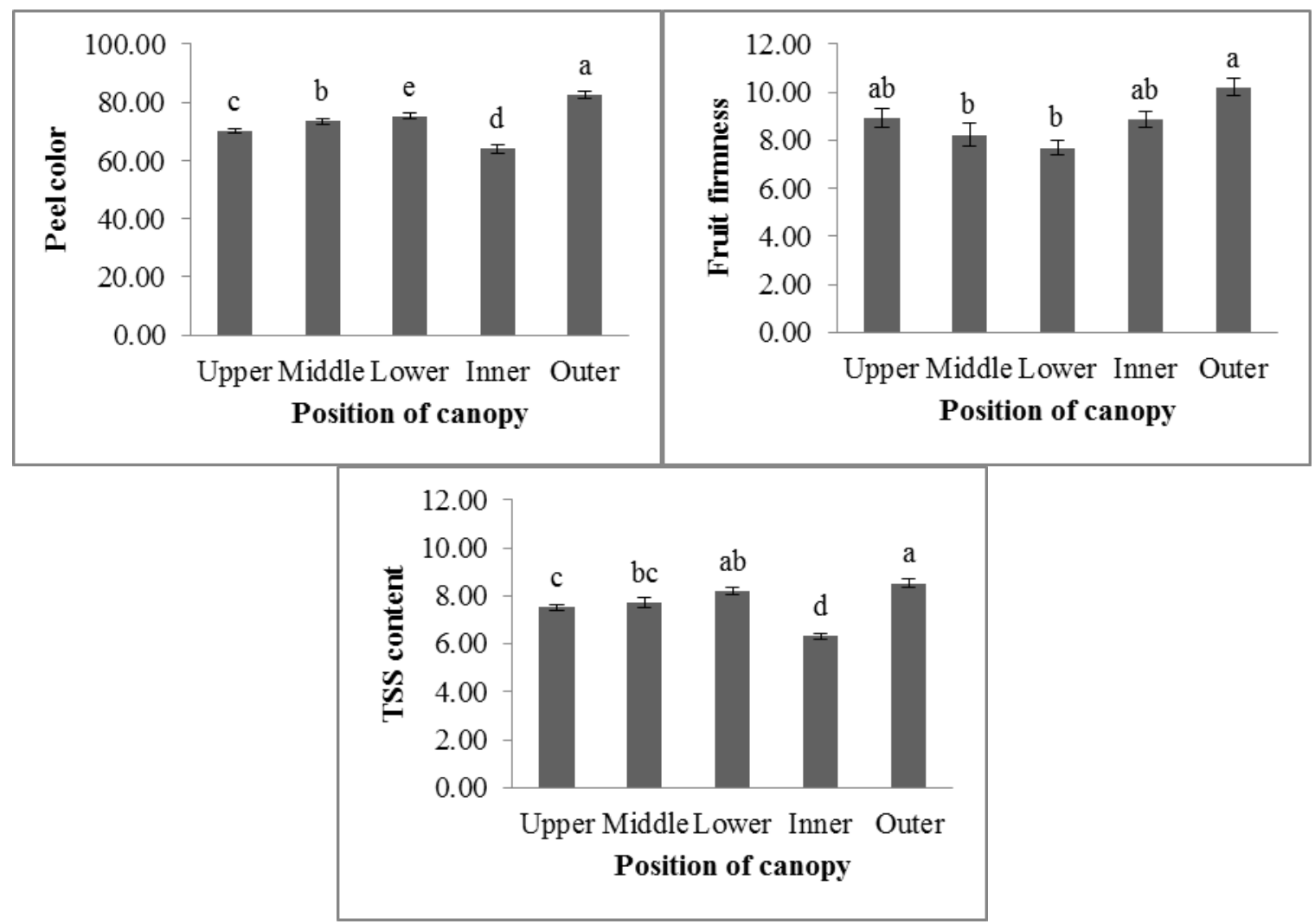

Fig 3. The effects of different canopy positions on peel color of fruit at 21 DAA, firmness of fruit and TSS content of fruit. Means within the same column of different line followed by the same letter, do not differ significantly according to LSD test at a $\alpha=0.01$, Bars indicate $( \pm$ S.E).

received only $2 \%\left(33 \mu \mathrm{mol} \mathrm{m}^{2} \mathrm{~s}^{1}\right)$ of full sunlight. Row direction also affects the percentage exposure to full sun.

\section{Effect of canopy position on chlorophyll content (SPAD) and stomatal conductance}

Leaf chlorophyll content is an important physiological parameter which indicates the tree health. Table 1 showed the result of chlorophyll content and stomatal conductance on different canopy position of wax apple trees. For chlorophyll content, treatment of outer canopy position showed the highest value chlorophyll content with $102.34 \pm 1.96$ followed by middle canopy position treatment with $93.4 \pm$ 0.87 (Table 1). While the lowest value of chlorophyll content was recorded in upper canopy position treatment with $44.5 \pm$ 1.83. The means differences of chlorophyll content in five different treatments showed a significant different at $(\mathrm{P} \leq$ $0.05)$ level. For stomatal conductance, the result showed the highest reading in outer canopy position with $131.6 \pm 0.56$ $\mathrm{mmol} / \mathrm{m}^{2} / \mathrm{s}^{1}$, followed by middle canopy with $88.34 \pm 0.68$ $\mathrm{mmol} / \mathrm{m}^{2} / \mathrm{s}^{1}$. The lowest reading of stomatal conductance was lower canopy position with $34.04 \pm 0.34 \mathrm{mmol} / \mathrm{m}^{2} / \mathrm{s}^{1}$ (Table 1). The means difference of stomatal conductance in five different treatments showed a significant different at $(\mathrm{P} \leq$ $0.05)$ level.

Our result showed that leaf chlorophyll content of wax apple tree significant differs among the canopies. Similar finding was reported by Nicholas et al (2002), who reported that the distribution of chlorophyll within a canopy can vary considerably as a function of time and space. Leaves chlorophyll content of wax apple also affected by growth regulators and phloemic stress application (Moneruzzaman et al. 2011 and 2012). Thus it can affect the production of trees as well as quality of fruits. Gas exchange depend on the density, size and degree of opening of the stomata; with more open stomata allowing greater conductance, and consequently indicating that photosynthesis and transpiration rates are potentially higher. Our result indicated that stomatal aperture was the highest in leaves of outer canopy. Mills et al (2008) also reported that leaf position in the canopy played a significant role in determining stomatal response within a 15 year-old tree of citrus.

Previous study on 'Granny Smith' apple trees in the Southern Hemisphere show that outer canopy fruit on the northern side of the tree were exposed to $53 \%$ of full daylight while inner canopy fruit close to trunk received only $2 \%$ of full daylight (Fouché et al., 2010). The location within a tree canopy influences the microclimate around individual fruits, which may lead to considerable variation in their external and internal qualities (Awad et al. 2000). 'Fuji' apple trees, the average level of photosynthetically active radiation is the lowest in the interior and lower portions of the canopy (Jakopic et al., 2009). Fruit that are perpetually exposed to sunlight may vary in quality from cover fruit and may subsequently have different postharvest attributes (Thompson, 2003).

\section{Materials and Methods}

\section{Experimental site and design}

The experiment was carried out at a commercial orchard located at Kampung Olak Lempit, Banting, Malaysia. The experiment was conducted between December 2015 and April 2016 at the field in Randomized Complete Block Design (RCBD) of 5 treatments (different canopy position viz; upper, lower, middle, inner and outer) with 5 replicates. Five (5) of fifteen-year-old wax apple trees that were planted 
in a $4.2 \mathrm{~m} \times 4.2 \mathrm{~m}$ hexagonal pattern and received the same horticultural management, were randomly selected for this study. For each tree, five (5) uniform branches of approximately the same length, diameter and number of leaves were selected (one sample branch for each canopy) and tagged by upper canopy (UC), middle canopy (MC), lower canopy (LC), inner canopy (IC) and outer canopy (OC) (Figure 1). A total of two hundred and fifty (250) fruits were harvested from the experimental trees, kept separately according to different canopy positions (50 fruits from each canopy position) and bought to the laboratory. All the harvested fruits were then kept in a refrigerator at $4^{\circ} \mathrm{C}$ prior to biochemical analysis.

\section{Measurement of growth and physiological parameters}

The data for growth parameters were collected during the field visit. On the first $\left(1^{\text {st }}\right)$ visit to the orchard in December, the measurement of the number of bud and size of bud produced had been taken. The number of bud was calculated and the size of bud $(\mathrm{cm})$ was measured by using Vernier caliper. On the second $\left(2^{\text {nd }}\right)$ visit, the number of dropped bud and blooming bud was calculated. In April, on the third ( $\left.3^{\text {rd }}\right)$ visit, the number of fruit produced from different canopy position was calculated. The fruits sizes were measured in term of fruit length $(\mathrm{cm})$ and width $(\mathrm{cm})$ by using Vernier caliper. The weights ( $\mathrm{g}$ ) of fruit produced by different canopy positions were measured by using electronic balance.

Chlorophyll content was measured by using a SPAD-502 meter (Minolta Japan). This SPAD meter was hand-held device that widely used for rapid, accurate and nondestructive measurement of leaf chlorophyll content by means of absorbance or transmittance measurements. Before using the meter, it was calibrated about 15 minutes so that the readings can be taken accurately. The measurement was taken by simply clamped over leafy tissue. Chlorophyll content was taken at every different canopy position in five replicate. Stomatal conductance of leaf was measured by using a portable Porometer (Leaf Porometer, Model SC-1, USA). Before measurement was taken, the leaf chamber was kept at an ambient temperature for 10 to 15 minutes to maintain sunlight adaptation. After that, a leaf chamber was attached to one leaf and the readings were showed on the screen of porometer. This measurement was taken by five replicates at different canopy position.

\section{Measurement of biochemical parameters}

The fruits samples that were collected from different positions then were cleaned. Total soluble solids (TSS) was evaluated at $25{ }^{\circ} \mathrm{C}$ with an Atago 8469 handheld refractometer (Atago Co. LTD., Tokyo, Japan) and expressed as ${ }^{\circ}$ Brix. The peel of fruit is removed and the fruits are cut into small cubes $\left(1 \mathrm{~cm}^{3}\right)$. The flesh of the fruit was crushed in mortar and pestle. 1 drop of fruit juice was placed to refractometer sensor and the reading was recorded. Fruit firmness was measured using a penetrometer. The fruit was penetrated with penetrometer and the reading was recorded. The peel color of the fruits was measured using a Minolta colorimeter (CR-300, Konica, Japan). Parameters such as lightness $(L)$, greenness to redness $(a)$ and blueness to yellowness $(b)$ were determined at three different spots around the top, middle and end of the fruits. Sample averages were calculated and the color was expressed in $L^{*}, a^{*}, b^{*}$ Hunter parameter, using the following formula $\left(L^{*} \times a^{*}\right) / b$.

\section{Statistical analysis}

The data obtained subjected to statistical analysis using OneWay Analysis of Variance (ANOVA) (SPSS software version 20.0) to determine significant difference on parameters measured. The means comparisons were performed with LSD test at $\dot{\alpha}=0.01$, significant value $\mathrm{p} \leq 0.05$.

\section{Conclusion}

Environmental and tree cultivation management practices significantly influence the external and internal characteristics of fruit. This can be proved from the information from this study that showed us the canopy position has greatly impacted on quality of wax apple fruit produced. Based on the overall results, OT position showed the positive effects on producing better quality and quantity of wax apple fruit. Number of fruit, fruit size, TSS content and peel color development were higher in outer canopy. Outer canopy also showed less bud dropped and stimulate higher stomatal conductance. It can be concluded that canopy position has significant effect on quality and quantity of fruit and fruits from outer canopy preserve the better quality. The study of light-induced pigment accumulation in leaves and ripening fruits of wax apple fruit merit further study.

\section{Acknowledgements}

The authors thank to Mr Hafidz Nazari for giving permission of conducting study on his field and Research Management, Innovation \& Commercialization Centre (RMIC) University of Sultan Zainal Abidin, Terengganu, Malaysia for publication support.

\section{References}

Awad MA, De Jager A, Van Westing LM (2000) Flavonoid and chlorogenic acid levels in apple fruit: characterization of variation. Scientia Hort. 83:249-263.

Blanpied GD, Bramlage WJ, Dewey DH, Labelle RL, Massey LM, Mattus G, Stiles WC, and Watada AE (1978) A standard method for collecting apple pressure test data. Bulletin no 74. Cornell Univ Agr Expt Station.

Bramlage WJ (1993) Interactions of orchard factors and mineral nutrition on quality of pome fruit. Acta Hort. 326:15-25.

Fouché JR, Roberts SC, Midgley SJE, Steyn WJ (2010) Peel color and blemishes in 'Granny Smith' apples in relation to canopy light environment. Hort Sci. 45(6):899-905.

Frick $T$ (1995) The relationship between temperature variables and fruit maturity of Bon Chretien' pears in four areas in the Western Cape. Thesis Master of Agriculture in Horticultural Science, University of Stellenbosch, South Africa.

Hamadziripi E (2012) Relationship between canopy position and fruit quality as it pertains to consumer liking. Thesis Master in Agriculture in Horticultural Science. University of Stellenbosch, South Africa.

Jakopic J, Stampar F, Veberic R (2009) The influence of exposure to light on the phenolic content of 'Fuji' apple. Sci Hort. 123: 234-239.

Khandaker MM, Normaniza O, Boyce AN (2012) The influence of hydrogen peroxide on the growth, development and quality of wax apple (Syzygium samarangense, [Blume] Merrill \& L.M. Perry var. jambu madu) fruits. Plant Physiol Biotech. 53:101-110. 
Kingston CM (1994) Maturity indices of apples and pears. Hort Rev. 408-414.

Lambers H, Chapin FS III, Pons TL (1998) Plant physiological ecology. York, PA, USA: Springer Verlag.

Lewallen KAS (2000) Effects of light availability and canopy position on peach fruit quality. Thesis submitted to the faculty of the Virginia polytechnic institute and state univ. $47 \mathrm{p}$.

Mills TM, Morgan KT, Parsons LR (2008) Canopy Position and Leaf Age Affect Stomatal Response and Water Use of Citrus. J Crop Prod. 2: 163-179.

Moneruzzaman KM, Hossain ABMS, Normaniza O, Saifuddin M, Sani W, Nasrulhaq-Boyce A (2010) Effects of removal of young leaves and kinetin on inflorescence development and bract enlargement of Bougainvillea glabra var." Elizabeth Angus". Aus J Crop Sci 4 (7):467-473.

Moneruzzaman KM, Hossain ABMS, Normaniza O, Boyce AN (2012) Application of girdling for improved fruit retention, yield and fruit quality in Syzygium samarangense under Field Conditions. Int J Agric Bio. 13: 18-24.

Moneruzzaman KM, Hossain ABMS, Normaniza O, Boyce AN (2011) Growth, yield and quality responses to gibberellic acid $\left(\mathrm{GA}_{3}\right)$ of wax apple Syzygium samarangense var. jambu air madu fruits grown under field conditions. Afr J Biotech. 56(10): 1911-11918.

Morton J (1987) Loquat. In: Morton, J.F. (ed.), Fruits of Warm Climates, pp: 103-108. Miami, Florida

Nicholas CC, Christine S, Darius SC, Laurie AC, Ray NM (2002) Chlorophyll content in eucalypt vegetation at the leaf and canopy scales as derived from high resolution spectral data. Tree Physiol. 23: 23-31.

Palmer JW (1989) Canopy manipulation for optimum utilization of light. In: Wright CJ (ed) Manipulation of fruiting. Butterworth \& Co., London.

Rudell DR, Mattheis JP, Curry EA (2008) Prestorage ultraviolet- white light irradiation alters apple peel metabolome. J Agril Food Chem. 56:1138-1147.
Shahak Y, Gussakovsky EE, Cohen Y (2004) ColorNets: A new approach for light manipulation in fruit trees. Acta Hort. 636:609-616.

Shu ZH, Tzong SL, Jung ML, Chi CH, Der NW, Hsiao HP (2007) The industry and progress review on the cultivation and physiology of wax apple with special reference to pink variety. Asian Aus J Plant Sci Biotechnol. 1(2): 48-53.

Steyn WJ, Wand SJE, Holcroft DM, Jacobs G (2005) Red colour development and loss in pears. Acta Hort. 671:7985.

Steyn WJ (2012) Physiology and functions of fruit pigments: An ecological and horticultural perspective. Hort Rev. 239271.

Tahir II, Johansson E, Olsson ME (2007) Improvement of quality and storability of apple cv. Aroma by adjustment of some pre-harvest conditions. Sci Hort. 112: 164-171.

Tomala K (1999) Orchard factors affecting fruit storage quality and prediction of harvest

date of apples. Acta Hort. 485:373-382.

Tombesi A, Antognozzi E, Palliotti A (1993) Influence of light exposure on characteristics and storage life of kiwifruit. New Zealand J Crop Hort Sci 21: 87-92.

Thompson AK (2003) Fruit and Vegetables: Harvesting, Handling and Storage, Second edition, Blackwell Publishing, Kent, 460p.

Wagenmakers PS, Callesen O (1995) Light distribution in apple orchard systems in relation to production and fruit quality. J Hort Sci. 70(6):935-948.

Wilkie JD, Margaret S, Trevor O (2008) Regulation of floral initiation in horticultural trees. J Exp Bot. 59 (12): 32153228.

Wünsche JN, Lakso AN (2000) Apple Tree PhysiologyImplications for orchard and tree management. In: Proceedings of the 43rd Annual IDFTA Conference. February 2000. Napier, New Zealand. 82-88. 